\title{
TITIK TEMU DAN SINERGI EKONOMI ISLAM DAN EKONOMI KERAKYATAN
}

\author{
Sofyan Rizal ${ }^{*}$
}

\begin{abstract}
Meeting Point and Sinergy of Islamic and Populist Economy. In fact, Islamic and populist economy have the same objective: they are welfare and fairness for all people. In Islam, the economical welfare and the fairness must be based on Islamic norms and ethics. Koperasi is a populist economic institution that has been long existed in Indonesia. Koperasi is the main institution that is expected by the founders of this nation as a tool of economical equality and fairness. At the concept of implementation level, koperasi has a lot of compatybility with the appropiate institutions of economic empowerment of Islam.
\end{abstract}

Keywords: Islamic economy, populist economy, Islamic koperasi

\begin{abstract}
Abstrak: Titik Temu dan Sinergi Ekonomi Islam dan Ekonomi Kerakyatan. Ekonomi Islam dan ekonomi kerakyatan sesungguhnya mempunyai tujuan yang sama, yaitu kesejahteraan dan keadilan dalam ekonomi bagi semua orang. Menurut Islam, keadilan dan kesejahteran dalam kehidupan ekonomi harus berlandaskan norma dan etika Islam, sehingga semua sistem ekonomi tersebut berjalan sesuai dengan syariat Islam. Ekonomi kerakyatan di Indonesia sudah berjalan sejak lama dengan institusi yang sudah dirancang, yaitu koperasi. Koperasi merupakan ujung tombak yang diharapkan oleh para pendiri bangsa ini sebagai alat untuk pemerataan dan keadilan ekonomi. Pada tataran konsep dan pelaksanaan, institusi koperasi mempunyai banyak kesesuaian dengan institusi pemberdayaan ekonomi yang diharapkan Islam.
\end{abstract}

Kata Kunci: ekonomi Islam, ekonomi kerakyatan, koperasi syariah

Naskah diterima: 4 Juni 2010, direvisi: 15 September 2010, disetujui: 23 September 2010.

* Universitas Nasional Jakarta. Jalan Sawo Manila, Pejaten, Pasar Minggu, Jakarta. E-mail: sofyanrizal@yahoo.com 


\section{Pendahuluan}

Kegagalan sistem ekonomi-baik sistem ekonomi sosialis yang berporos pada begitu besarnya peran pemerintah terhadap kehidupan rakyat, yang kemudian runtuh dengan tumbangnya rezim komunis Uni Sovyet, juga ekonomi kapitalis, yang menyebabkan kekayaan terpusat pada segelintir orang atau negara, dan menyebabkan semakin besarnya ketimpangan antara kaya dan miskin-membuat banyak orang kemudian berpikir untuk terus mencari alternatif sistem ekonomi yang dapat memecahkan masalah akibat kegagalan dua sistem tersebut.

Indonesia, sebagai negara yang menganut sistem ekonomi kapitalis, mengalami hal serupa, dengan krisis berkepanjangan yang sampai saat ini belum seorang ahlipun yang memastikan bahwa Indonesia telah keluar dari krisis. Saat ini, berjuta-juta orang menganggur, puluhan juta orang berada di bawah garis kemiskinan, sektor moneter yang semakin jauh dari sektor riil sehingga berpotensi meledakkan bubble economic ${ }^{l}$ yang sudah terbentuk, dan pelbagai macam masalah melingkupi kehidupan perekonomian Indonesia. Lahirnya sejumlah pengusaha besar (konglomerat) yang bukan merupakan hasil derivasi dari kemampuan manejemen bisnis yang baik menyebabkan fondasi ekonomi nasional yang dibangun berstruktur rapuh terhadap persaingan pasar. Mereka tidak bisa diandalkan untuk menopang perekonomian nasional dalam sistem ekonomi pasar. Padahal ekonomi pasar diperlukan untuk menentukan harga yang tepat (price right) untuk menentukan posisi tawar-menawar yang imbang.

Ini pula yang menyebabkan sebagian masyarakat kembali berpikir untuk mencari alternatif sistem ekonomi yang lebih dapat menyejahterakan rakyat. Ekonomi Islam yang sebenarnya sudah ada ribuan tahun yang lalu (sejak jaman Rasulullah Saw.) perlahan kembali bangkit dan menggeliat. Pelbagai macam kajian tentang ekonomi Islam bermunculan. Institusi-institusi ekonomi Islam seperti bank syariah, koperasi syariah, Baitulmal wa Tamwil (BMT), dan BPR syariah pun tumbuh dengan subur. Institusi pendidikan yang menggali ekonomi Islam juga menggeliat dan terus tumbuh.

Ekonomi kerakyatan, sebagai khazanah pemikiran ekonom Indonesia pun mulai diperbincangkan orang, kemudian dikuatkan dengan TAP MPR No. XVI/1998. Istilah ekonomi kerakyatan ini kemudian semakin dimantapkan dalam

${ }^{1}$ Suatu perekonomian dengan adanya gap yang sangat besar antara sektor moneter dengan sektor riil, sehingga kelihatan perekonomian besar karena besarnya sektor moneter, tetapi hal itu tidak membawa dampak pada sektor riil. 
banyak TAP MPR berikutnya termasuk kemudian UU No. 25/2000 tentang Propenas.

Demokrasi ekonomi, yang antara lain berisikan tentang keberpihakan yang sangat kuat terhadap usaha kecil-menengah serta koperasi adalah inti dari ekonomi kerakyatan. Keputusan politik ini sebenarnya menandai suatu babak baru pembangunan ekonomi nasional dengan perspektif yang baru, di mana bangun ekonomi yang mendominasi struktur ekonomi nasional mendapat tempat tersendiri. Komitmen pemerintah adalah untuk mengurangi gap penguasaan aset ekonomi antara sebagian besar pelaku ekonomi di tingkat rakyat dan sebagian kecil pengusaha besar (konglomerat). Hasil yang diharapkan adalah terciptanya struktur ekonomi yang berimbang antar pelaku ekonomi dalam negeri, demi mengamankan pencapaian target pertumbuhan (growth). Bahwa kegagalan kebijakan pembangunan ekonomi nasional masa orde baru dengan keberpihakan yang berlebihan terhadap kelompok pengusaha besar perlu diubah. Sudah saatnya dan cukup adil jika pengusaha kecil-menengah dan bangun usaha koperasi mendapat kesempatan secara ekonomi untuk berkembang sekaligus mengejar ketertinggalan yang selama ini mewarnai buruknya tampilan struktur ekonomi nasional.

Artikel ini akan membahas ekonomi kerakyatan dalam perspektif ekonomi syariah. Pembahasan akan dimulai dari pengertian dan pelaksanaan ekonomi kerakyatan, kemudian seputar ekonomi Islam. Hal ini untuk memberi gambaran untuk melihat hubungan antara ekonomi kerakyatan dan ekonomi Islam. Bagian selanjutnya akan melihat bagaimana perspektif ekonomi Islam terhadap ekonomi kerakyatan.

\section{Ekonomi Kerakyatan}

Ekonomi rakyat secara harfiah dilahirkan oleh ahli-ahli ekonomi Indonesia sebagai usaha untuk menggali potensi ekonomi rakyat Indonesia melalui sistem ekonomi alternatif yang sebenarnya sudah dijalankan oleh rakyat. Secara praktik, ekonomi kerakyatan sudah dijalankan oleh rakyat sebelum kata ekonomi kerakyatan itu lahir. $^{2}$

Ekonomi rakyat atau ekonomi kerakyatan ${ }^{3}$ bukanlah sebuah mazhab ekonomi baru, namun hanya sebagai suatu konstruksi pemahaman dari realita

${ }^{2}$ Mengenai sejarah ekonomi kerakyatan, lihat dalam Mubyanto, "Membangkitkan Ekonomi Kerakyatan melalui Gerakan Koperasi”, dalam Jurnal Ekonomi Rakyat, Tahun. 1 No. 6, 2002.

${ }^{3}$ Beberapa ahli mendefinisikan ekonomi rakyat berbeda dengan ekonomi kerakyatan. Abimanyu mengatakan bahwa ekonomi rakyat adalah satuan ekonomi yang berskala kecil, sedangkan ekonomi kerakyatan lebih merupakan kata sifat yang lebih luas (lihat, Abimayu, 2000, h. 
ekonomi yang umum terdapat di negara berkembang. Suatu realita ekonomi di mana selain ada sektor formal yang umumnya didominasi oleh usaha dan konglomerat terdapat sektor informal di mana sebagian besar anggota masyara-kat hidup ${ }^{4}$. Oleh karena itu, ekonomi rakyat berkembang sesuai dengan kondisi masyarakat di suatu daerah tertentu.

Begitu banyak definisi tentang ekonomi rakyat, namun satu hal yang tampaknya menjadi pokok ekonomi rakyat adalah perekonomian ini dari rakyat, oleh rakyat, dan untuk rakyat. ${ }^{5}$ Ekonomi yang digerakkan oleh usaha-usaha rakyat, terutama usaha kecil dan menengah yang dilakukan oleh rakyat banyak, untuk kemudian hasilnya pun akan kembali kepada rakyat. Karena sifatnya yang merata, persebaran modal yang baik, sistem ekonomi yang benar-benar bergerak dalam sektor riil, ekonomi rakyat mempunyai dampak pemerataan terhadap pendapatan yang baik dan mampu menggerakkan sektor riil secara efektif. Dalam dunia usaha, ekonomi rakyat adalah usaha-usaha kecil dan menengah yang dijalankan oleh rakyat.

Pada negara-negara maju seperti Amerika, misalnya, penciptaan lapangan kerja yang diciptakan oleh bisnis kecil begitu dominan. Di Jerman, perusahaan yang digolongkan dalam bisnis kecil menghasilkan 2/3 produk nasional bruto (GDP). Di Amerika, 87,5 \% tenaga kerja bekerja pada usaha kecil (usaha dengan jumlah SDM di bawah 20 orang) ${ }^{6}$. Mereka menyadari bahwa usaha kecil adalah penopang pembangunan sehingga intervensi pemerintah pada negara kapitalis seperti Amerika tetap dilakukan bahkan dengan sangat intens untuk membantu usaha kecil. ${ }^{7}$ Di Indonesia, ketika perusahaan-perusahaan dan bank-bank raksasa terpuruk oleh krisis ekonomi, usaha kecil relatif dapat bertahan menghadapi gempuran krisis tersebut. Terbukti, setelah krisis, usaha yang kadangkala disebut usaha informal tetap eksis dan malah bermunculan di manamana.

Menurut data BPS, jumlah usaha kecil, menengah, dan koperasi di Indonesia sekitar 36 juta usaha. Bagian terbesar yaitu sebesar 34 juta jiwa adalah

139; Baswir, 1997, h. 4). Pada artikel ini penulis memakai pendapat yang menyamakan ekonomi rakyat dan kerakyatan (Mubyarto, Ekonomi Rakyat Indonesia, 2002).

${ }^{4}$ Bambang Ismawan, "Ekonomi Rakyat, Sebuah Pengantar", dalam Jurnal Ekonomi Rakyat, Th 1 No. 1, 2002.

${ }^{5}$ Bayu Krisnamurthi, "Krisis Ekonomi Moneter dan Ekonomi Rakyat", dalam Jurnal Ekonomi Rakyat, Th 1, No. 3, 2002.

${ }^{6}$ Griffin \& Ebert, 2004, Business, (New Jersey: Pearson Prentice Hall, t.th.), h. 64-65.

${ }^{7}$ Amerika mempunyai badan pemerintah yang bernama Small Business Administration (SBA) yang berfungsi untuk membantu usaha-usaha berskala kecil. Lihat, Griffin \& Ebert, Business, h. 64-65. 
usaha mikro, baru diikuti oleh usaha kecil, koperasi, dan usaha menengah. Sektor ini pada tahun 2000 menyerap 99,6\% tenaga kerja Indonesia.

Berdasarkan hal tersebut, tampaknya titik tekan ekonomi rakyat adalah bagaimana memberdayakan rakyat dalam perekonomian dan keberpihakan pemerintah kepada rakyat dalam hal ekonomi, serta memastikan tidak terjadinya ketidakadilan ekonomi karena adanya perlakuan yang tidak sama antara pemilik modal besar dengan rakyat sehingga timbul ketimpangan ekonomi.

Pertama, karakteristik ekonomi rakyat. Sebagai sebuah entitas ekonomi yang cakupannya sangat signifikan dan $\operatorname{luas}^{8}$, karakteristik yang dimiliki ekonomi rakyat sangat beragam, tergantung dari jenis kegiatan yang dimaksud. Meskipun demikian, kiranya dapat digambarkan beberapa karakteristik dasar antara lain informalitas, mobilitas, bersifat keluarga, kemandirian, dan berhubungan dengan sektor formal. ${ }^{9}$

Informalitas dalam arti ekonomi kerakyatan sebagian besar bergerak di luar kerangka legal dan pengaturan yang ada. Adanya kelemahan-kelemahan dalam aturan ekonomi yang ada atau ketidakmampuan pemerintah untuk membuat sistem dan kemudian memakai sistem yang ada (dan seringkali dianggap tidak memihak usaha kecil dan rakyat), membuat ekonomi kerakyatan ini berkembang dengan subur. Namun hal ini juga berimplikasi negatif, misalnya dengan sifatnya yang informal menyebabkan akses modal ke lembaga keuangan formal seperti bank dan bantuan pemerintah menjadi sangat terbatas. Akibat dari hal ini, maka kadang kala sektor informal harus berhubungan dengan lembaga keuangan nonformal yang berbunga sangat tinggi. Kenyataan ini sering dijumpai di lapangan, misalnya nelayan dan petani yang harus meminjam uang kepada rentenir dan akhirnya terjerat dengan utang.

Karakteristik informal ini tampaknya sebagai suatu usaha yang inovatif dari masyarakat untuk memulai usaha atau mengatasi persoalan modal dalam memulai usaha, dan hambatan-hambatan birokrasi yang terjadi juga karena terbatasnya akses informasi masyarakat tentang aturan-aturan usaha.

Aspek mobilitas sebenarnya hal yang sangat wajar terjadi dalam sebuah sistem pasar. $^{10}$ Pada ekonomi kerakyatan yang mempunyai sifat informal, membawa konsekuensi tiadanya jaminan yang pasti akan keberlangsungan

\footnotetext{
${ }^{8}$ Mengenai signifikansi potensi dan realisasi ekonomi kerakyatan, lihat data BPS tahun 2000 sebagaimana disadur Bambang Ismawan, "Ekonomi Rakyat, Sebuah Pengantar".

${ }^{9}$ Bambang Ismawan, "Ekonomi Rakyat, Sebuah Pengantar".

10 Dalam Ekonomi Konvensional dikenal dengan The Firm's Long-Run Decision to Exit or Enter A Market, Keseimbangan dalam industri yang terjadi karena masuk dan keluarnya pelaku pasar karena dipengaruhi perilaku mengejar profit. Lihat Mankiw, The Principles of Economics, (Orlando: Harcourt Inc, 2001), h. 300.
} 
aktivitas yang dijalani. Faktor eksternal sangat berpengaruh secara langsung dan cepat. Exit and entrance to market menjadi hal yang sangat mudah dilakukan. Sebagai contoh, apabila dalam satu sektor industri atau pasar terdapat peluang yang begitu terbuka dan menguntungkan, maka segera banyak yang akan terjun ke dalamnya. Begitupun bila market tersebut tidak menguntungkan lagi, maka dengan cepat sektor tersebut ditinggalkan. Sebagai contoh, kasus tumbuh suburnya wartel, yang kala itu menjanjikan keuntungan yang sangat besar untuk ukuran usaha kecil. Masyarakat merespons dengan mendirikan wartel di manamana, sehingga yang terjadi malah sekarang market untuk wartel menjadi jenuh. Pengecualian karakteristik ini terjadi pada sektor pertanian dan perikanan.

Karakteristik ini tampak menjadi keunggulan ekonomi kerakyatan, karena mekanisme yang dikembangkan untuk merespons tantangan ekonomi akibat berubahnya situasi dan kondisi eksternal dengan melakukan diversifikasi aktivitas ekonomi secara cepat dan mudah.

Kemandirian ekonomi kerakyatan adalah implikasi dari persepsi yang berkembang di masyarakat, pemerintah maupun pelaku ekonomi lain, sehingga membatasi interaksi dengan ekonomi kerakyatan. Ekonomi kerakyatan masih dianggap sebagai sektor yang berisiko tinggi dan tidak bankable ${ }^{11}$, sehingga tidak mempunyai akses terhadap perbankan dan investasi. Pada pemerintah, ekonomi kerakyatan masih dianggap sebagai sektor penanggulangan kemiskinan dan pemberdayaan usaha kecil dan menengah, sehingga masih digarap secara kurang serius. Perlakuan seperti ini kemudian mendorong ekonomi kerakyatan menjadi mandiri.

Kedua, akar filosofis dan historis ekonomi kerakyatan. Ekonomi kerakyatan tidak terlepas dari pengalaman bangsa Indonesia yang mengalami penjajahan yang cukup lama. Oleh penjajah Belanda, rakyat pribumi hanya menjadi sapi perahan yang dilakukan sewenang-wenang dalam segala sektor, termasuk dalam bidang ekonomi.

Sebagai perlawanan ekonomi terhadap Belanda, maka dilatarbelakangi keinginan untuk menyejahterakan umat Islam, Haji Saman Hudi mendirikan Sarekat Dagang Islam (SDI) pada tahun 1909. Berdirinya SDI dapat dikatakan sebagai bangkitnya ekonomi kerakyatan. Wujud keberpihakan SDI terhadap umat dan masyarakat ini tergambar dalam anggaran dasarnya yang menegaskan bahwa organisasi ini akan berikhtiar supaya anggota-anggotanya satu sama lain bergaul seperti saudara, diupayakan timbullah kerjasama dan tolong-menolong

${ }^{11}$ Bankable adalah proposal usaha atau usaha yang tidak laik mendapatkan pinjaman dari bank karena faktor dan penilaian tertentu. 
satu sama lain, serta bergaul seperti saudara antara sekalian Muslim ${ }^{12}$. Boleh dikatakan umat Islam dengan SDI-nya adalah pencetus ekonomi kerakyatan yang saat itu termotivasi untuk melawan kesewenang-wenangan Belanda dalam sektor ekonomi. Dalam masa kemerdekaan, bahkan ekonomi kerakyatan menjadi satu cita-cita para pendiri bangsa ini. Hal ini tercermin dari UUD 1945 Pasal 33.

Ketiga, nilai dasar ekonomi kerakyatan. Nilai dasar ekonomi kerakyatan adalah keadilan sosial dan pemerataan ekonomi ${ }^{13}$. Pembangunan ekonomi Indonesia harus bertumpu pada keadilan sosial. Seluruh aktivitas ekonomi masyarakat harus mencerminkan keadilan. Dalam konteks doktrin ekonomi, maka hal ini dapat dilihat pada Pasal 33 Undang-Undang Dasar 1945: (1) Perekonomian disusun sebagai usaha bersama berdasarkan azas kekeluargaan. (2) Cabang-cabang produksi yang penting bagi negara dan menguasai hajat hidup orang banyak, dikuasai oleh negara. (3) Bumi, air dan kekayaan alam yang terkandung di dalamnya dikuasai oleh negara dan dipergunakan sebesarbesarnya untuk kemakmuran rakyat.

Prinsip-prinsip usaha bersama berdasarkan kekeluargaan adalah prinsip usaha saling tolong-menolong, saling asuh, dan seimbang. Negara berfungsi sebagai fasilitator dan pengawas terhadap aktivitas usaha anggota masyarakat. Sebagai fasilitator, negara akan menyediakan sarana, prasarana, undang-undang, peraturan yang kondusif bagi terlaksananya sistem ekonomi tersebut. Sebagai pengawas, maka negara mengawasi dan menindak jika terjadi praktik usaha yang tidak sesuai dengan prinsip tersebut, seperti monopoli.

Cabang produksi yang penting dikuasai oleh negara untuk menghindari penguasaan swasta terhadap sektor produksi yang penting bagi masyarakat. Kekayaan alam yang terkandung di dalamnya juga seharusnya dikuasai oleh negara, bukan oleh sektor swasta.

Keempat, pemerataan ekonomi. Pemerataan ekonomi bukanlah berarti bahwa semua masyarakat harus mendapatkan hasil yang sama dalam usaha. Pemerataan ekonomi adalah pemerataan kesempatan dalam menjalankan usaha atau perekonomian. Perlakuan yang sama pada setiap orang tanpa diskriminasi. Pada Pasal 27 UUD 1945 dikatakan bahwa setiap orang berhak atas pekerjaan dan penghidupan yang laik bagi kemanusiaan. Ini artinya bahwa setiap orang berhak memperoleh aset ekonomi secara adil dan merata sesuai dengan bakat dan keahlian yang dimilikinya. Penguasaan atas sumber pendapatan oleh satu kelompok akan bertentangan dengan semangat keadilan sosial.

\footnotetext{
12 Dainy Tara, Strategi Membangun Ekonomi Rakyat, (Jakarta: Nuansa Madani, 2001).

${ }^{13}$ Dainy Tara, Strategi Membangun Ekonomi Rakyat, h. 21.
} 
Keadilan sosial dan pemerataan ekonomi mempunyai hubungan yang sangat erat dan tidak terpisahkan. Terciptanya keadilan sosial akan menjamin terwujudnya pemerataan ekonomi.

\section{Ekonomi Islam}

Allah Swt. berfirman:

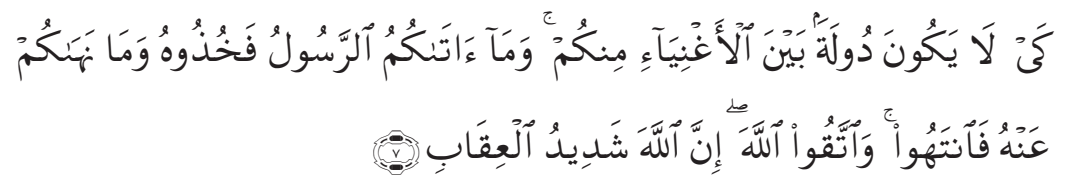

Supaya harta itu jangan beredar di antara orang-orang kaya saja di antara kamu. Apa yang diberikan Rasul kepadamu, maka terimalah dan apa yang dilarangnya bagimu, maka tinggalkanlah. Dan bertakwalah kepada Allah. Sesungguhnya Allah amat keras hukumannya. (Q.s. al-Hasyr [59]: 7)

Pemerataan pendapatan inilah yang sebenarnya menjadi kendala besar bagi ekonomi kapitalis. Mereka berpendapat bahwa kemakmuran itu seperti air yang dituangkan ke dalam gelas. Bila gelas sudah penuh, maka airpun akan melimpah ke daerah di sekitarnya. Namun mereka lupa, bahwa manusia yang bebas nilai tidak akan cukup dengan harta sebanyak apapun. Timbullah ketimpangan ekonomi, ketidakmerataan pendapatan yang semakin hari semakin besar. Ini yang menjadi salah satu tujuan ekonomi Islam. Ada nilai moral yaitu qanâ'ah, menghindari mubazir, tidak serakah, tidak bersifat konsumtif. Ada instrumen pemerataan seperti zakat, infak, dan sedekah. Ada peran pemerintah (tadâkhul dawliyyah) yang menjaga maqâshid, menjaga kemaslahatan orang banyak.

Maqâshid syarîah menurut al-Ghazâlî adalah meningkatkan kesejahteraan seluruh manusia yang terletak pada perlindungan keimanan, jiwa, akal, keturunan dan kekayaan mereka. Apapun yang menjamin kelima hal ini menjamin kepentingan publik dan merupakan hal yang diinginkan ${ }^{14 "}$.

Pada awal masa berkembangnya, ekonomi Islam juga diwarnai dengan aturan-aturan tidak tertulis yang sangat dijunjung tinggi oleh generasi awal mula Islam. Kita sering mendengar kisah para pedagang dan pengusaha (konglomerat) yang sangat memperhatikan kepentingan umat (rakyat) seperti kisah

${ }^{14}$ Umar Chapra, The Future Of Economics: An Islamic Perspective , (Jakarta: SEBI, 2001), h. 124 . 
'Utsmân ibn 'Affân yang menginfakkan hartanya ketika Medinah dalam masa paceklik. Sumbangan yang tidak tanggung-tanggung, ratusan ekor onta beserta barang dagangan yang ada pada onta tersebut. Inilah norma aturan tidak tertulis yang lahir dari inner beauty, keluhuran moral generasi Islam dahulu sehingga adanya miskin dan kaya dijalani sebagai suatu nikmat, dan pemerataan ekonomi berjalan dengan landasan moral.

Islam, jelas dalam setiap sektornya, termasuk sektor ekonomi, sangat memperhatikan moral dan norma-norma syariah, sehingga apapun yang bertentangan dengan syariah, dan bertentangan juga dengan maqâshid syarî‘ah, akan ditolak. Sedangkan ekonomi kerakyatan, yang sangat berpihak pada kepentingan rakyat banyak, sangat powerfull pada bagaimana pemerataan pendapatan dan kesempatan sehingga masyarakat dapat menikmati kesejahteraan. Sinergi yang paling efektif adalah menanamkan nilai moral dan syariah pada ekonomi kerakyatan. Kehalalan, kejujuran, keadilan, menghindari kezaliman, menghindari kemubaziran dan hal yang tidak bermanfaat, menghindari hal yang haram adalah suatu nilai moral yang dapat meningkatkan nilai lebih dari sinergi ini.

Inilah sebenarnya salah satu titik tekan ekonomi dalam Islam, selain instrumen bebas riba dengan segala derivasinya, dalam sistem ekonomi Islam. Ekonomi yang berlandaskan pada moral yang tinggi. Semua orang boleh menjadi kaya, boleh menjadi besar jika memungkinkan, namun dengan aturan yang jelas, sesuai syariat, tidak menzalimi, berlaku adil, asas kesetimbangan, bermanfaat bagi orang banyak dan peduli dengan sesama.

\section{Ekonomi Islam dan Sistem Ekonomi Lainnya}

Sistem ekonomi Islam berbeda dari kapitalisme, sosialisme, maupun negara kesejahteraan (welfare state). ${ }^{15}$ Berbeda dari kapitalisme karena Islam menentang eksploitasi oleh pemilik modal terhadap buruh yang miskin, dan melarang penumpukan kekayaan.

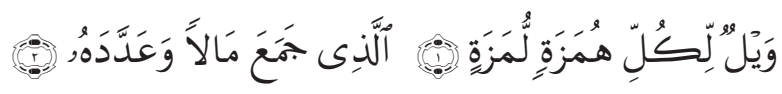

Kecelakaanlah bagi setiap pengumpat lagi pencela, yang mengumpulkan harta dan kemudian menghitung-hitung. (Q.s. al-Humazah [104]: 1-2)

\footnotetext{
${ }^{15}$ Lihat Mannan, Teori dan Praktik Ekonomi Islam, (Jogjakarta: DBW, 19970, h.309-344.
} 
Ajaran Islam yang paling nyata adalah menjunjung tinggi upaya pemerataan untuk mewujudkan keadilan sosial, yang tercermin dalam Q.s. al- $\underline{\text { Hasyr }}$ [59]: 7 di atas.

Disandingkan dengan sosialisme, Islam berbeda dalam hal kekuasaan negara, yang dalam sosialisme sangat kuat dan menentukan. Kebebasan individu diakui dan dinilai tinggi dalam Islam jelas bertentangan dengan ajaran sosialisme.

Ajaran ekonomi kesejahteraan (welfare state) yang berada di tengahtengah antara kapitalisme dan sosialisme memang lebih dekat ke ajaran Islam. Bedanya hanyalah bahwa dalam Islam etika benar-benar dijadikan pedoman perilaku ekonomi sedangkan dalam welfare state tidak demikian, karena etika welfare state adalah sekuler yang tidak mengarahkan pada integrasi vertikal antara aspirasi materi dan spiritual.

\section{Ekonomi Islam dan Ekonomi Kerakyatan}

Untuk melihat titik temu dari ekonomi Islam dan ekonomi kerakyatan, maka perlu kiranya kita melihat tujuan dari masing-masing. Sistem ekonomi Islam mempunyai tujuan sebagai berikut: ${ }^{16}$ Pertama, kesejahteraan ekonomi dalam kerangka norma moral Islam (Q.s. al-Baqarah [2]: 2 \& 168, Q.s. al-Mâ'idah [4]: 87-88, Q.s. al-Jumu'ah [62]: 10. Kedua, membentuk masyarakat dengan tatanan sosial yang solid, berdasarkan keadilan, dan persaudaraan yang universal (Q.s. al-Hujurât [49]: 13, Q.s. al-Mâ'idah [4]: 8, Q.s. al-Syu'arâ [26] 183. Ketiga, mencapai distribusi pendapatan dan kekayaan yang adil dan merata (Q.s. alAn'âm [6]: 165, al-Nahl [16]: 71, al-Zukhruf [43]: 32. Keempat, menciptakan kebebasan individu dalam konteks kesejahteraan sosial (Q.s. al-Ra'd [13]: 36, Q.s. Luqmân [31]: 22).

Sementara itu, tujuan ekonomi kerakyatan dapat dirumuskan menjadi empat tujuan pokok. ${ }^{17}$ Pertama, mewujudkan pemerataan dan keadilan sosial yaitu tidak membiarkan terjadi dan berkembangnya ketimpangan ekonomi dan kesenjangan sosial. Kedua, semangat nasionalisme ekonomi, dimana dalam era globalisasi makin jelas adanya urgensi terwujudnya perekonomian nasional yang kuat, tangguh, dan mandiri. Ketiga, demokrasi ekonomi berdasar kerakyatan dan kekeluargaan, koperasi dan usaha-usaha kooperatif menjiwai perilaku ekonomi perorangan dan masyarakat. Keempat, keseimbangan yang harmonis, efisien, dan adil, antara perencanaan nasional dengan desentralisasi ekonomi dan

${ }^{16}$ Lihat M. Syafii Antonio, Bank Syariah dari Teori ke Praktik, (Jakarta: GIP, 2001), h. 10-18.

${ }^{17}$ Mubyanto ," Ekonomi rakyat dan Reformasi kebijakan", dalam Jurnal Ekonomi Rakyat, Th 3 No. 6 Tahun 2004. 
otonomi yang luas, bebas, dan bertanggung jawab, menuju perwujudan keadilan sosial bagi seluruh rakyat Indonesia.

Islam bertujuan membentuk masyarakat dengan tatanan sosial yang solid. Dalam tatanan yang solid tersebut setiap individu diikat oleh persaudaraan dan kasih sayang. Tatanan yang solid akan tercapai bila keadilan dalam masyarakat dipenuhi termasuk keadilan ekonomi. Kesenjangan pendapatan dan kekayaan yang berlangsung di masyarakat tentu berlawanan dengan konsep keadilan ekonomi. Kesenjangan ini yang ingin diatasi oleh ekonomi Islam .

Cara yang ditempuh oleh Islam, misalnya dengan memperkecil peluangpeluang monopoli dan pemusatan penguasaan sektor ekonomi yang sangat besar pada beberapa pihak tertentu, menjamin hak dan kesempatan semua pihak untuk aktif dalam seluruh proses kegiatan ekonomi, menjamin pemenuhan kebutuhan dasar, dan melaksanakan sistem jaminan sosial. Keadilan ekonomi yang diterapkan Islam, selain berlandaskan asas syariah, tetapi tetap mengakui kebebasan individu dalam berusaha asal sesuai dengan bingkai syariah. Bingkai tersebut antara lain kepentingan orang banyak lebih didahulukan daripada kepentingan individu.

Pemerataan keadilan sosial yang menjadi tujuan dari ekonomi kerakyatan jelas sesuai dan telah ter-cover dalam tujuan ekonomi Islam. Ketimpangan ekonomi dan kesenjangan sosial yang ingin diatasi oleh ekonomi kerakyatan memang menjadi titik perhatian dari ekonomi Islam. Demokrasi ekonomi yang ingin memberikan kesempatan seluas-luasnya kepada masyarakat untuk menjadi pelaku ekonomi tanpa diskriminasi dikembangkan pula dalam ekonomi Islam. Bahkan Islam pun mengatur campur tangan pemerintah dalam sektor yang menyangkut hajat hidup orang banyak dengan membolehkan pemerintah memegang monopoli pada sektor tertentu. Ini dilakukan agar kebutuhan masyarakat terhadap public good dapat terjamin, misalnya: air, energi, barang tambang, dan hutan. Keseimbangan yang harmonis dan adil serta otonomi ekonomi yang bertanggungjawab juga menjadi perhatian dalam Islam yang diakui dalam kebebasan individu yang bertanggung jawab dalam konteks kesejahteraan sosial bersama.

\section{Konsep Sharing dalam Ekonomi Islam dan Kerakyatan}

Konsep kebersamaan dan tolong-menolong dalam menghadapi ketidakpastian merupakan salah satu prinsip yang sangat mendasar dalam ekonomi Islam. Konsep ini dapat dianggap mendukung aspek keadilan yang merupakan prinsip dalam ekonomi Islam. Konsep kebersamaan dalam ekonomi Islam ini termasuk di dalamnya kebersamaan menanggung risiko dan ketidakpastian 
dalam berusaha. Konsep ini kemudian dikenal dengan istilah sharing atau profit sharing. Penetapan suatu hasil di depan dan kemudian mengesampingkan risiko dari seorang yang berusaha dipandang sebagai sesuatu yang tidak adil.

Konsep sharing dalam Islam berkembang menjadi ujung tombak ekonomi Islam yang mewarnai praktik institusi ekonomi Islam. Konsep itu terjelma misalnya dalam akad-akad transaksi dan kerjasama antara masyarakat, antara masyarakat dengan lembaga-lembaga permodalan, antara masyarakat dengan investor, ataupun antara masyarakat dengan pelaku usaha langsung. Akad itu dikenal dengan mudhârabah dengan segala derivasi pengembangannya.

Pada ekonomi kerakyatan, sistem yang dikembangkan adalah sistem yang sebenarnya lebih sempit yaitu share ownership. Konsep share ownership ini kemudian diejawantahkan dalam institusi yang bernama koperasi. Koperasi di Indonesia identik dengan wadah perekonomian masyarakat Indonesia. Bahkan, koperasi pada awal berdirinya republik ini diharapkan menjadi sokoguru perekonomian Indonesia, walaupun dalam perkembangannya harapan ini tidak kunjung terwujud, bahkan boleh dikatakan gagal.

\section{Koperasi Syariah: Titik Temu Institusi Ekonomi}

Sebagai pilar terpenting ekonomi bangsa yang diharapkan menjadi sokoguru perekonomian, secara ironis koperasi justru jauh tertinggal dari badan usaha swasta dan perusahaan negara. Peran penting koperasi dalam mendorong pemberdayaan, pemerataan, dan demokrasi ekonomi ini telah dibuktikan di pelbagai negara di seluruh dunia. Namun realitas memperlihatkan perkembangan koperasi hingga kini masih memprihatinkan. Dari 140 ribu koperasi yang ada di Indonesia, hanya 28,5\% yang aktif, dan lebih sedikit lagi koperasi yang memiliki manajemen kelembagaan yang baik, partisipasi anggota yang optimal, usaha yang fokus, terlebih lagi skala usaha yang besar.

Institusi ekonomi yang menyentuh rakyat banyak baik dalam Islam maupun dalam ekonomi kerakyatan akan tepat bertemu pada koperasi. Oleh karena itulah pendekatan yang paling mungkin dan tepat secara institusi adalah koperasi syariah atau koperasi dengan menggunakan prinsip-prinsip syariah dalam pelaksanaannya. Koperasi syariah adalah usaha ekonomi yang terorganisir secara mantap, demokratis, otonom, partisipasif, dan berwatak sosial yang operasionalnya menggunakan prinsip-prinsip yang mengusung etika moral dan berusaha dengan memperhatikan halal atau haram sebuah usaha yang 
dijalankan sebagaimana diajarkan dalam agama Islam $^{18}$. Mengapa koperasi syariah? Karena perekonomian Islam yang dibangun dengan prinsip bebas riba tentu akan menolak segala hal yang berkaitan dengannya. Koperasi, walaupun Ia sebuah institusi ekonomi yang merakyat, namun tidak terlepas dari unsur riba. Sedangkan prinsip koperasi yang lain bisa dikatakan sesuai dan bahkan didukung oleh Islam, seperti shareownership, bagi hasil usaha, keberpihakan pada masyarakat, dan prinsip positif lainnya.

Kini terdapat lebih dari 3000 koperasi syariah di Indonesia yang dalam waktu relatif singkat telah mampu membantu lebih dari 920.000 usaha mikro di tanah air dan telah merambah ke seluruh kabupaten di tanah air baik dalam bentuk koperasi pondok pesantren (kopontren), koperasi masjid, koperasi perkantoran, hingga koperasi pasar (kopas). Secara konseptual, koperasi sendiri pada hakikatnya sangat selaras dengan budaya dan nilai-nilai Islam, agama mayoritas di negeri ini. Tidak heran bila kemudian koperasi yang beroperasi berdasarkan syariat Islam, dengan mudah diterima oleh masyarakat Indonesia. Dalam perspektif Islam, koperasi yang menjunjung asas kebersamaan dan kekeluargaan dapat dipandang sebagai bentuk syirkah ta'âwuniyyah yang bermakna bekerja sama dan tolong-menolong dalam kebaikan. Ketika koperasi bekerja dalam bingkai syariah Islam, seperti tidak berhubungan dengan aktivitas riba, maysir (judi), dan gharar (spekulan), maka lengkaplah keselarasan koperasi dengan nilai-nilai Islam.

\section{Sinergi Ekonomi Syariah dan Kerakyatan}

Tidaklah bijaksana bila terjebak terus-menerus pada konsep dan definisi tentang ekonomi kerakyatan ataupun ekonomi Islam, apalagi berdasarkan uraian di atas, sesungguhnya dapat dikatakan ekonomi Islam adalah ekonomi kerakyatan yang berjalan di atas norma-norma dan etika berlandaskan syariah. Begitu pula dalam konteks institusi ekonomi. Institusi ekonomi Islam dan ekonomi kerakyatan yang bertemu pada institusi koperasi telah berjalan dan telah ada di masyarakat. Hal yang lebih diperlukan adalah bagaimana semua konsep tersebut dapat berjalan dan bersinergi sehingga membuat kemiskinan di tengah masyarakat menjadi berkurang dan keadilan ekonomi ditegakkan.

Sesungguhnya masing-masing instrumen ekonomi tersebut sudah berjalan dan eksis di masyarakat. Sekadar contoh, instrumen ekonomi kerakyatan semacam koperasi sudah lama ada dan sampai saat ini masih terus berkembang

18 Nur S. Buchori, Pengelolaan Koperasi syariah, (Jakarta: Departemen UMKM Bidang Ekuintek DPP PKS, 2007), hal 2. 
walaupun porsinya masih teramat kecil dibandingkan usaha lainnya. Data dari Departemen Koperasi menunjukkan saat ini modal koperasi hanya sekitar 3,5 Trilyun saja, dengan jumlah koperasi sebanyak 97 ribuan. Sektor UKM atau sektor lain yang sering dipinggirkan dengan sebutan sektor informal seperti pedagang kecil, kaki lima dan lain sebagainya, yang notabene bagian dari ekonomi kerakyatan pun sudah tumbuh sedemikian rupa. Bahkan sektor UKM inilah yang paling banyak menyerap tenaga kerja dan menjadi solusi menanggulangi pengangguran yang semakin meningkat.

Begitupun yang terjadi dengan koperasi syariah. Kini terdapat lebih dari 3.000 koperasi syariah di Indonesia yang dalam waktu relatif singkat telah mampu membantu lebih dari 920.000 usaha mikro di tanah air dan telah merambah ke seluruh kabupaten di tanah air baik dalam bentuk koperasi pondok pesantren (kopontren), koperasi masjid, koperasi perkantoran, hingga koperasi pasar (kopas). Secara konseptual, koperasi sendiri pada hakikatnya sangat selaras dengan budaya dan nilai-nilai Islam, agama mayoritas di negeri ini. Tidak heran bila kemudian koperasi yang beroperasi berdasarkan syariat Islam dengan mudah diterima oleh masyarakat Indonesia.

Dalam perspektif Islam, koperasi yang menjunjung asas kebersamaan dan kekeluargaan dapat dipandang sebagai bentuk syirkah ta'âwuniyyah yang bermakna bekerja sama dan tolong-menolong dalam kebaikan. Ketika koperasi bekerja dalam bingkai syariah Islam, seperti tidak berhubungan dengan aktivitas riba, maysir (judi), dan gharar (spekulan), maka lengkaplah keselarasan koperasi dengan nilai-nilai Islam. Hal positif yang paling diperlukan adalah bagaimana agar kedua institusi tersebut dapat lebih berkembang dan maju sehingga dapat menjadi kekuatan ekonomi yang sesungguhnya dan bisa berdampak pada tujuan yang dicita-citakan masing-masing.

Ada beberapa syarat yang dapat menjadi faktor majunya koperasi, antara lain: ${ }^{19}$ Pertama, koperasi akan mampu berperan secara baik kepada masyarakat ketika koperasi secara benar berjalan sesuai jati dirinya sebagai suatu organisasi otonom, lembaga yang diawasi anggotanya dan bila mereka tetap berpegang pada nilai dan prinsip koperasi. Kedua, potensi koperasi dapat diwujudkan semaksimal mungkin hanya bila kekhususan koperasi dihormati dalam peraturan perundangan. Ketiga, koperasi dapat mencapai tujuannya bila mereka diakui keberadaannya dan aktivitasnya. Keempat, koperasi dapat hidup seperti laiknya perusahaan lainnya bila terjadi fair playing field. Kelima, pemerintah

${ }^{19}$ Noer Sutrisno, "Koperasi Mewujudkan Kebersamaan dan Kesejahteraan", dalam Jurnal Ekonomi Rakyat,Th. 2 No. 5, 2003. 
harus memberikan aturan main yang jelas, tetapi koperasi dapat dan harus mengatur dirinya sendiri di dalam lingkungan mereka (self-regulation). Keenam, koperasi adalah milik anggota di mana saham adalah modal dasar, sehingga mereka harus mengembangkan sumber dayanya dengan tidak mengancam identitas dan jati dirinya. Ketujuh, bantuan pengembangan dapat berarti penting bagi pertumbuhan koperasi, namun akan lebih efektif bila dipandang sebagai kemitraan dengan menjunjung tinggi hakekat koperasi dan diselenggarakan dalam kerangka jaringan.

Syarat kemajuan koperasi tersebut sesungguhnya memiliki dua faktor utama yaitu masyarakat dan pemerintah. Masyarakat berperan dalam memberdayakan koperasi dengan pengelolaan yang profesional, transparan, dan akuntabel. Pengelolaan koperasi harus dengan sumber daya manusia yang unggul. Koperasi tidak dijadikan sebagai alat untuk mendapatkan dana dari pemerintah, ataupun proyek keluarga atau perangkat pemerintahan.

Pemerintah berperan dalam memajukan koperasi dengan mengeluarkan peraturan-peraturan dan kebijakan yang mendukung. Pemerintah dituntut untuk memiliki komitmen yang kuat untuk menjalankan peraturan dan kebijakan yang memihak koperasi, bukan menjadikannya sebagai komoditas politik apalagi lahan penyelewengan dana. Fungsi pemerintah sebagai regulator juga dituntut berperan dengan aktif, misalnya memberikan aturan main yang jelas bagi koperasi dan iklim usaha secara umum. Fungsi pemerintah sebagai pengayom koperasi pun sangat penting diperhatikan, dengan bukan hanya memberikan bantuan dana saja, namun juga pembinaan, pengawasan, pemberdayaan dan pastisipasi aktif koperasi dalam sektor usaha.

Negara sumber kapitalis, seperti Amerika, sesungguhnya tidak menjalankan ekonomi kapitalis secara murni. Mereka masih memproteksi rakyatnya pada bidang tertentu seperti sektor pertanian. Mereka punya lembaga pemberdayaan ekonomi kecil yaitu SBA (Small Business Administration) yang berfokus pada peningkatan usaha kecil. Mereka memberlakukan undang-undang antimonopoli secara ketat. Sektor-sektor publik seperti jalan tol, bandara, dan pelabuhan menjadi milik negara untuk dipergunakan sebesar-besarnya kemakmuran rakyat. Hal ini demi meningkatkan pemberdayaan ekonomi rakyatnya.

Pemerintahan kita, malah sedang giat-giatnya melakukan kapitalisme "murni" yang sudah ditinggalkan orang. Usaha kecil dan menengah tidak terkelola dengan baik. Sebagai contoh, pasar pemerintah, yang banyak diisi oleh pedagang kecil dan menengah terpinggirkan oleh pasar modern dan hipermarket. Ini bukanlah semata hasil persaingan yang fair. Ketika pasar pemerintah tidak dikelola dengan baik, kumuh, berdesakan, panas, becek, banyak copet, pungli, 
dan lain sebagainya, yang mengakibatkan ekonomi biaya tinggi, bagaimana bisa bersaing dengan hypermarket yang nyaman. Mengapa tidak pemerintah memodernisasi pasar tradisional, menghilangkan pungli dan lain sebagainya, sehingga kompetisi yang terjadi adalah kompetisi yang fair. Belum lagi bicara masalah modal UKM. Akses terhadap modal dan pinjaman terbatas atau kalaupun ada, sangat sulit dan berbiaya tinggi. Keberpihakan kepada perusahaan besar semakin kuat. Hal ini dapat dilihat dari indikasi keberpihakan pemerintah terhadap bank-bank konvensional, peraturan kompetisi yang kurang tegas. Privatisasi asetaset milik negara terus berlangsung, padahal jelas ditegaskan sumber hajat hidup orang banyak dikuasai oleh negara untuk kepentingan rakyat. Kekayaan alam yang begitu berlimpah malah dinikmati sebagian besar oleh pihak asing. Ekonomi bebas bunga yang diusung oleh sistem ekonomi Islam pun masih belum direspon secara penuh oleh pemerintah. Zakat, yang merupakan potensi sangat besar untuk mengentaskan kemiskinan masih belum didukung oleh peraturan yang baik untuk mengoptimalisasikan pengelolaannya. Hasilnya, perolehan zakat yang ada hanya $2 \%$ dari potensi filantropi masyarakat.

Padahal, potensi berkembangnya ekonomi Islam dan kerakyatan sangatlah besar. Koperasi, yang jaringannya sampai ke desa-desa adalah sebuah aset ekonomi jaringan rakyat yang berharga. Jika pemerintah punya peraturan yang cukup dan komitmen yang kuat untuk pemberdayaan koperasi baik SDM maupun modal dan kesempatan, maka koperasi akan menjadi kekuatan besar dalam menggerakkan sektor riil. Perbankan syariah atau lembaga keuangan syariah, tumbuh sangat baik, walaupun kondisi masyarakat yang multikrisis dan dukungan pemerintah yang kurang. BMT sebagai jaringan akses modal yang luas bagi masyarakat menengah ke bawah, dengan jumlah yang masih sangat terbatas saja sudah dapat dirasakan manfaatnya.

\section{Belajar dari Orang Lain}

Menarik apa yang dilakukan Muhammad Yunus dengan instrumen ekonomi kerakyatannya di Banglades yang bernama Grameen Bank, Banking for the Poor. Sebagaimana yang diceritakan Reynald Kasali dalam bukunya, Recode Your Change $D N A^{20}$, beliau melihat kemiskinan di masyarakatnya sudah begitu merajalela, karena masyarakat terjerat pada rentenir, padahal mereka hanya membutuhkan bantuan beberapa dolar saja. Hal yang banyak orang mampu melakukannya. Dengan koperasi yang sangat sederhana, melayani kaum wanita di desa, bahkan sampai pengemis, dengan pinjaman bebas bunga pada awalnya dan berbunga sangat rendah setelah mampu, dengan sistem grouping, Grameen

\footnotetext{
${ }^{20}$ Reynald Kasali, Re-code Your Change DNA, (Jakarta: Gramedia, 2007), h. 94-97.
} 
Bank telah menolong berjuta-juta orang terbebas dari kemiskinan. Sampai tahun 2004, Grameen Bank telah menyalurkan pinjaman mikro sebesar \$ 4,5 Milliard. Inilah yang sedang dan seharusnya dilakukan oleh BMT-BMT di daerah-daerah, sehingga akses terhadap modal bagi usaha kecil dapat lebih mudah.

Keberhasilan lain, juga terjadi pada koperasi di India yang sekarang sudah menjadi perusahaan raksasa yang sahamnya dimiliki oleh anggota masyarakat kecil. Koperasi itu adalah Gujarat Cooperative Milk Marketing Federation (GCMMF). Usaha raksasa yang awalnya adalah koperasi susu yang didirikan untuk melawan ketidakberdayaan permainan harga susu dari pabrik besar. Dengan pola semacam Induk koperasi yang membawahi beberapa jaringan KUD, GCMMF yang didirikan tahun 1946, saat ini menjadi produsen pelbagai macam produk susu terbesar di India dengan penjualan tahunan sebesar $\$ 500 \mathrm{Juta}^{21}$.

\section{Penutup}

Ekonomi Islam dan ekonomi kerakyatan sesungguhnya mempunyai tujuan yang sama, yaitu kesejahteraan dan keadilan dalam ekonomi bagi semua orang. Keadilan dan kesejahteran dalam kehidupan ekonomi tersebut, dalam Islam harus berlandaskan pada norma dan etika Islam, sehingga semua sistem ekonomi tersebut berjalan sesuai dengan syariah Islam.

Selain merupakan konsep yang berlandaskan pada keadilan sosial dan pemerataan ekonomi yang adil, sesungguhnya ekonomi kerakyatan di Indonesia sudah berjalan sejak lama dengan institusi yang sudah dirancang, yaitu koperasi. Koperasi merupakan ujung tombak yang diharapkan oleh para pendiri bangsa ini sebagai alat untuk pemerataan dan keadilan ekonomi.

Institusi koperasi pada tataran konsep dan pelaksanaannya banyak memiliki kesesuaian dengan institusi pemberdayaan ekonomi yang diharapkan Islam. Oleh karena itulah, ekonomi syariah mengkonversi institusi koperasi itu dengan koperasi syariah.

Sinergi dari institusi ini diharapkan dapat menjadi ujung tombak sistem ekonomi Islam sebagai ekonomi kerakyatan. Hal ini dapat terwujud mengingat potensi yang begitu besar dari koperasi, yang menjangkau sampai kepada lapisan masayarakat terkecil. Potensi itu juga terlihat pada koperasi syariah, yang saat ini baru berupa BMT yang keberadaannya sangat membantu sektor informal dalam mengakses modal. Hal yang juga sangat penting agar ekonomi syariahyang berbasis kerakyatan-ini berhasil adalah dukungan dan komitmen pemerintah dalam hal regulasi, kebijakan dan peraturan yang mendukung. [ ]

${ }^{21}$ Lihat, Prasanda Chandra, Who Want to be an Interpreneur, (Jakarta: Prestasi Pustaka, 2006), h.178-185. 


\section{Pustaka Acuan}

\section{Buku:}

Antonio, Muhammad Syafi'i, Bank Syariah dari Teori ke Praktik, Jakarta: GIP, 2001.

Buchori, S. Nur, Pengelolaan Koperasi Syariah, Jakarta: Departemen UMKM DPP PKS, 2007.

Chandra, Prasanna, Who Wants To Be An Enterpreneur, Jakarta: Prestasi Pustaka, 2006.

Chapra, M. Umar, The Future of Economics: an Islamic Perspective, Jakarta: SEBI, 2001.

Griffin, Ricky W, and Ronald J. Ebert, Business, ew Jersey: Pearson Prentic Hall, N 2004.

Kasali, Reynald, Re-Code Your Change DNA, Jakarta: Gramedia, 2007.

Mankiw, N Gregory, Principles Of Economics, Second Edition, Harcourt: Orlando, 2001.

Mannan, M Abdul, Teori dan Praktik Ekonomi Islam, Terjemahan oleh Nastangin, Yogyakarta: Dana Bhakti Wakaf, 1997.

\section{Artikel/Makalah:}

Ismawan, Bambang "Ekonomi Rakyat, Sebuah Pengantar", dalam Jurnal Ekonomi Rakyat, Tahun 1, No. 1, 2002.

Krisnamurthi, Bayu, "Krisis Ekonomi Moneter dan Ekonomi Rakyat", dalam Jurnal Ekonomi Rakyat, Tahun 1, No. 3, 2002.

Mubyanto, "Ekonomi Rakyat dan Reformasi Kebijakan", dalam Jurnal Ekonomi Rakyat, Tahun 3, No. 6, 2004.

----------, "Membangkitkan Ekonomi Kerakyatan Melalui Gerakan Koperasi", dalam Jurnal Ekonomi Rakyat, Tahun 1, No. 6, 2002.

Sutrisno, Noer, "Koperasi Mewujudkan Kebersamaan dan Kesejahteraan", dalam Jurnal Ekonomi Rakyat Tahun, 2, No. 5, 2003. 